\title{
Critical Review of Different Methods for Siting and Sizing Distributed-generators
}

\author{
Shomefun TS*, Ademola A, Awosope COA, Adekitan Al \\ Department of Electrical and Information Engineering, Covenant University, Canaan land, KM 10, \\ Idiroko, Road, P.M.B. 1023, Ota, Ogun State, Nigeria \\ *Corresponding author, e-mail: tobi.shomefun@covenantuniversity.edu.ng
}

\begin{abstract}
Due to several benefits attached to distributed generators such as reduction in line losses, improved voltage profile, reliable system etc., the study on how to optimally site and size distributed generators has been on the increase for more than two decades. This has propelled several researchers to explore various scientific and engineering powerful simulation tools, valid and reliable scientific methods like analytical, meta-heuristic and hybrid methods to optimally place and size distributed generator(s) for optimal benefits. This study gives a critical review of different methods used in siting and sizing distributed generators alongside their results, test systems and gaps in literature.
\end{abstract}

Keywords: distributed generator; analytical; meta-heuristic; hybrid; site \& size

Copyright $@ 2018$ Universitas Ahmad Dahlan. All rights reserved.

\section{Introduction}

Electric power system (EPS) is one of the most complex conceptions by mankind, and it is a non-linear system. Aside this, its construction and operation are very complex and complicated because of several factors and constraints that must be considered in terms of location, type, available resources, etc. The purpose of Electrical Power System (EPS) is to generate and supply electrical energy to users [1]. It comprises generation station, transmission network, distribution network and load centres. The load centres receive and consume generated power by the generation stations via the link of transmission and distribution networks. However, in a deregulated electricity market, congestion on transmission lines maybe unavoidable because of insufficient capacity of lines [2]. Moreso, under voltages and over voltages in the lines lead to poor power quality and lack of stable power system [3]. Not with standing, power engineers during planning stage, give a margin or forecast to accommodate future load demand on the network, however, development brings about increase in the load demand which will outgrow the specified margin at some points. Hence, there will be need for expansion when load demand equals or greater than the supply power from generation stations.

On the contrary, construction of a new generation station requires a huge capital. This has propelled several researchers to investigate alternative means to offset overshoot in load demand against the supplied power from the generation stations. One major solution discovered was the installation of distributed generator (DG) close to the load centres. Though there are some other solutions, DG gives the best option to overcome load demand, economic and environmental challenges [4] among other methods such as FACTS devices for power system improvement, network reconfiguration, capacitor compensation, static VAR etc. [5-16]. Review of work done with distributed generators, will be the area of focus in this work.

\section{What then is Distributed Generator?}

Several researchers have put forward diverse definitions of distributed generator as given in [4], [6], [17-26]. According to CIRED (1999), there is no consensus yet on the generally acceptable definition of DG. However, the definition given by T. Ackermann et al. 
in [17] will suffice for this work. It is defined as "the electric power generation source linked directly to distribution network or the meter side of customer". Other criteria for which DG can be classified are given in Figure 1 [27]. Unlike conventional Central Generation (CG), distributed generation is not location bound (as the name implies). Table 1 gives comparison between CG and DG.

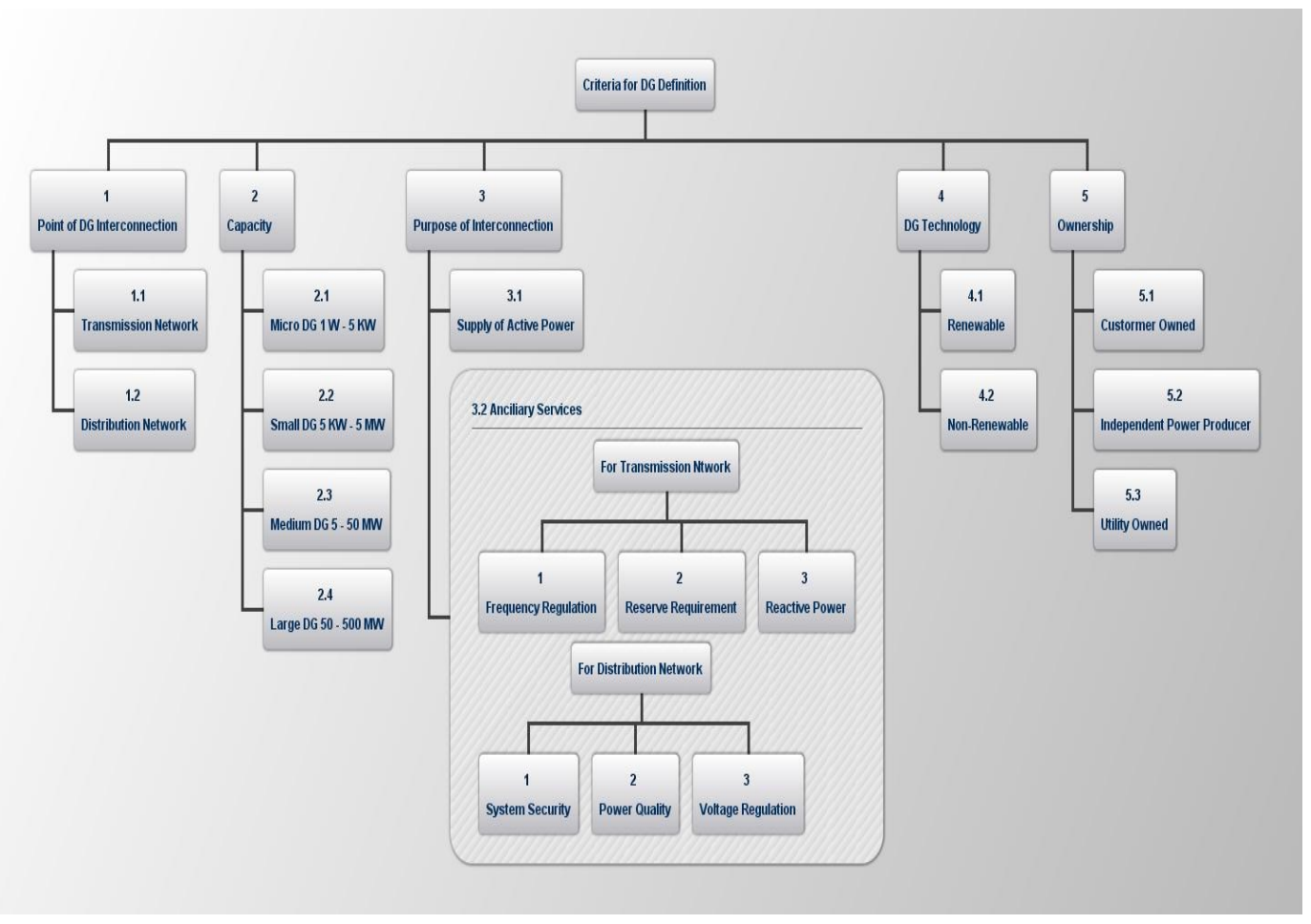

Figure 1. Criteria for DG classification

Table 1. Comparison between Central Generation and Distributed Generation

\begin{tabular}{cll}
\hline S/N & CentralGeneration & Distributed Generation \\
\hline 1 & Centrally located & It is not location bound. It is distributed \\
2 & Specific site of installation & It can be installed anywhere in which energy source is present \\
3 & Excellent economies of scale & Small-scale power generation technologies (in the range of \\
& Transmits electricity over a long & Transmits electricity over a short distance \\
4 & $\begin{array}{l}\text { Trantance } \\
\text { distand }\end{array}$ & Environmental friendly \\
5 & Negatively affects the environment & It can be isolated or integrated into the grid \\
6 & It is part of the grid & The technologies adopted in DG comprise small gas turbines, \\
7 & Basically, gas and hydro turbine & micro-turbines, fuel cells, wind and solar energy, biomass, \\
& & small hydro-power etc.
\end{tabular}

\section{Significance of Distributed Generator}

According to the IEA (2002), there are five major factors that contribute to the advancement in distributed generation namely; developments in distributed generation technologies, constraints on the construction of new transmission lines, increased customer demand for highly reliable electricity, the electricity market liberalization and concerns about climate change. However, these factors can be summarized under these two key issues: cost effectiveness of distributed generation and friendly environmental impact. This is because DG technology is being developed (not explored) continuously because it is cost effective. Also, DG saves a huge amount of money that would have been budgeted for transmission lines. Meanwhile, consumers can only demand for a 
reliable system that is affordable. However, no investors will like to venture into any business that is not profit oriented. And lastly, advent of renewable energy sources (RES) technology, which is free from greenhouse gas emission, mitigates concerns about climate change since they are environment friendly and readily available by nature. Hence, it can be said that Installation of distributed generation permits the utilization of freely available fuel opportunities [6].

Installation of DG is a short-time project and it is a less expensive alternative for electric power system expansion compared to construction of a new generation station $[24,27]$. Employing this method will not only help to meet load demand but also, improve voltage profile, increase the system reliability level [27], minimize Total Harmonic Distortion (THD) [28], minimize cost of electricity [29], lower short-circuit level [30], relieve transmission and distribution congestion and minimize line losses. This is because it is located closer to the point of consumption than the main source for the distribution network [31].

However, with so much positive impacts which DG adds to electric power system, it must be strategically and optimally located to achieve the intended results [24]. It must also be properly and optimally sized to avoid excessive generation cost, increase in the power loss, and bus voltage fluctuating in and out of the statutory limit [18, 32, 33].

Several researchers have used various methods to site and size distributed generator(s) ranging from analytical methods to hybrid-based optimization methods. Some of these methods are Gradient and second-order method, Hereford Ranch algorithm, Heuristic iterative method, Analytical based on 2/3 rule, Tabu search, Hybrid fuzzy nonlinear goal programming, Heuristic iterative search method, Linear programming, Sensitivity analysis, Hybrid e-constraint-based multi-objective programming, Optimal power flow, GA, Mixed integer non-linear programming, Iterative search technique with load flow [34]. The details of the various methodologies that have been deployed to date are as presented in Table 2. Techniques for DG placement differ, and they are dependent on the objectives to be achieved. These techniques have their strengths and drawbacks. Table 3 gives detailed comparison of these techniques.

Table 2. Different Methods Used in Siting and Sizing DG with Test System, Result and Observed Gaps

\begin{tabular}{|c|c|c|c|c|c|}
\hline $\begin{array}{l}\mathrm{S} / \\
\mathrm{N}\end{array}$ & Methodology & Test System & Result & Gaps & Reference \\
\hline$A$ & ANALYTIC & & & & \\
\hline 1 & $\begin{array}{l}\text { Analytical method } \\
\text { based on exact loss } \\
\text { formula }\end{array}$ & $\begin{array}{l}\text { Nigerian 33- } \\
\text { kV network }\end{array}$ & $\begin{array}{l}6.2 \% \text { reduction in active power } \\
\text { losses on the } 33-\mathrm{kV} \text { Nigerian } \\
\text { network (i.e. from } 92.7 \mathrm{MW} \text { to } \\
87.0 \mathrm{MW} \text { ). The results showed } \\
\text { an improvement in the voltage } \\
\text { profile of the six load buses } \\
\text { whose voltages were outside the } \\
\text { statutory limit of between } 0.95 \\
\text { pu and } 1.05 \mathrm{pu}\end{array}$ & $\begin{array}{l}\text { The work } \\
\text { required that } \\
\text { DG should } \\
\text { be installed } \\
\text { at each bus. } \\
\text { The } \\
\text { methods } \\
\text { cannot } \\
\text { optimally } \\
\text { place DGs. }\end{array}$ & $\begin{array}{l}\text { J. N. } \\
\text { Nweke, A. } \\
\text { O. Ekwue } \\
\text { and E. C. } \\
\text { Ejiogu [1] }\end{array}$ \\
\hline 2 & $\begin{array}{l}\text { Loss sensitivity } \\
\text { factor based on } \\
\text { current injection } \\
\text { method }\end{array}$ & $\begin{array}{l}\text { 12-, 34- and } \\
69-\text {-bus } \\
\text { distribution } \\
\text { test systems }\end{array}$ & $\begin{array}{l}\text { Proposed method (i.e. Current } \\
\text { injection) alongside with } \\
\text { Acharya's method and the } \\
\text { Classical grid search algorithm } \\
\text { were compared. The results for } \\
\text { the proposed method and } \\
\text { Acharya's method are almost } \\
\text { the same for optimum sizes and } \\
\text { estimated power losses. Based } \\
\text { on the test systems, the optimal } \\
\text { locations for DG are busses } 9 \text {, } \\
21 \text { and } 61 \text { respectively. } \\
\text { The proposed method is } 1.5 \\
\text { times faster than the Acharya's } \\
\text { method. However, Classical grid } \\
\text { search algorithm gives a worse } \\
\text { result. }\end{array}$ & $\begin{array}{l}\text { It did not } \\
\text { consider } \\
\text { different } \\
\text { types of load } \\
\text { models in } \\
\text { the analysis. }\end{array}$ & $\begin{array}{l}\text { Tuba } \\
\text { Gözel, M. } \\
\text { Hakan } \\
\text { Hocaoglu } \\
{[17]}\end{array}$ \\
\hline
\end{tabular}


Table 2. Different Methods Used in Siting and Sizing DG with Test System, Result and Observed Gaps

\begin{tabular}{|c|c|c|c|c|c|}
\hline $\begin{array}{l}\mathrm{S} / \\
\mathrm{N}\end{array}$ & Methodology & Test System & Result & Gaps & Reference \\
\hline 3 & $\begin{array}{l}\mathrm{N}-\mathrm{R} \text { method for load } \\
\text { flow study }\end{array}$ & $\begin{array}{l}\text { IEEE 6-bus, } \\
\text { IEEE 14-bus } \\
\text { and IEEE } \\
\text { 30-bus } \\
\text { systems }\end{array}$ & $\begin{array}{l}\text { For 6-, 14-, and 30-bus systems } \\
\text { considered, a minimum value of } \\
\text { Optimal Flow (OF) is obtained } \\
\text { when DG is placed at bus nos. } \\
3(6 \mathrm{MW}), 8(16 \mathrm{MW}) \text { and } \\
11(35 \mathrm{MW}) \text { respectively. }\end{array}$ & $\begin{array}{l}\text { It did not } \\
\text { specify the } \\
\text { type of DG } \\
\text { technology. } \\
\text { Likewise, it } \\
\text { did not } \\
\text { consider } \\
\text { different } \\
\text { types of load } \\
\text { models in } \\
\text { the analysis. }\end{array}$ & $\begin{array}{l}\text { Sudipta } \\
\text { Ghosh, } \\
\text { S.P. } \\
\text { Ghoshal, } \\
\text { Saradindu } \\
\text { Ghosh } \\
\text { [18] }\end{array}$ \\
\hline 4 & Power flow algorithm & $\begin{array}{l}\text { 13-bus } \\
\text { radial } \\
\text { system }\end{array}$ & $\begin{array}{l}\text { Optimal size and placement of } \\
\text { the theoretical analysis are valid } \\
\text { for constant power, current and } \\
\text { impedance load models. It is } \\
\text { found that the optimum location } \\
\text { does not change with the } \\
\text { chosen model. }\end{array}$ & $\begin{array}{l}\text { DG } \\
\text { technology } \\
\text { used was } \\
\text { not } \\
\text { specified, } \\
\text { method is } \\
\text { limited to } \\
\text { non-complex } \\
\text { network, } \\
\text { hence single } \\
\text { DG } \\
\text { placement. }\end{array}$ & $\begin{array}{l}\text { T. Gozel, } \\
\text { M. H. } \\
\text { Hocaoglu, } \\
\text { U. } \\
\text { Eminoglu, } \\
\text { and A. } \\
\text { Balikci [19] }\end{array}$ \\
\hline 5 & $\begin{array}{l}\text { Second-order power } \\
\text { flow sensitivities, }\end{array}$ & $\begin{array}{l}\text { 70-bus } \\
\text { distribution } \\
\text { system }\end{array}$ & $\begin{array}{l}\text { The results show that the total } \\
\text { power losses are dependent on } \\
\text { the DG location }\end{array}$ & $\begin{array}{l}\text { The method } \\
\text { cannot } \\
\text { randomly } \\
\text { find optimal } \\
\text { location for } \\
\text { DG }\end{array}$ & $\begin{array}{l}\text { Hugo M. } \\
\text { Ayres and } \\
\text { Walmir } \\
\text { Freitas } \\
\text { [20] }\end{array}$ \\
\hline 6 & Exact loss formula & $\begin{array}{l}\text { 30-bus, 32- } \\
\text { branch loop } \\
\text { system, 33- } \\
\text { bus, 32- } \\
\text { branch and } \\
69-\text {-bus, 68- } \\
\text { branch } \\
\text { radial } \\
\text { systems }\end{array}$ & $\begin{array}{l}\text { The result gives } 59.6 \%, 47.3 \% \\
\text { and } 62.8 \% \text { reductions in the } \\
\text { active power loss of the three } \\
\text { test systems respectively. }\end{array}$ & $\begin{array}{l}\text { It did not } \\
\text { specify the } \\
\text { type of DG } \\
\text { technology } \\
\text { used and } \\
\text { types of load } \\
\text { models } \\
\text { considered } \\
\text { in the } \\
\text { analysis. }\end{array}$ & $\begin{array}{l}\text { Naresh } \\
\text { Acharya, } \\
\text { Pukar } \\
\text { Mahat, N. } \\
\text { Mithulana } \\
\text { nthan [21] }\end{array}$ \\
\hline 7 & $\begin{array}{l}\text { Method based on } \\
\text { load flow }\end{array}$ & $\begin{array}{l}\text { IEEE 13- } \\
\text { and } 37 \text {-bus } \\
\text { distribution } \\
\text { test systems }\end{array}$ & $\begin{array}{l}\text { In the } 13 \& 37 \text {-bus distribution } \\
\text { test systems, the optimum sizes } \\
\text { range from } 1 \text { to } 1.7 \mathrm{MW} \& 0.7 \text { to } \\
10 \text { respectively. }\end{array}$ & $\begin{array}{l}\text { It did not } \\
\text { specify the } \\
\text { type of DG } \\
\text { technology } \\
\text { used and } \\
\text { types of load } \\
\text { models } \\
\text { considered } \\
\text { in the } \\
\text { analysis. }\end{array}$ & $\begin{array}{l}\text { P. Alemi } \\
\text { and G.B. } \\
\text { Gharehpet } \\
\text { ian [22] }\end{array}$ \\
\hline 8 & $\begin{array}{l}\text { Second-order } \\
\text { algorithm }\end{array}$ & $\begin{array}{l}\text { Six-bus } 25- \\
\mathrm{kV} \\
\text { distribution } \\
\text { network with } \\
\text { lines ranging } \\
\text { in length } \\
\text { from } 16 \text { to } \\
32 \mathrm{~km}\end{array}$ & $\begin{array}{l}\text { The total injection is maximally } \\
\text { distributed to nodes } 2,3,4 \text { and } 6 \\
\text { for loss minimization. }\end{array}$ & $\begin{array}{l}\text { It did not } \\
\text { specify the } \\
\text { type of DG } \\
\text { technology } \\
\text { used and } \\
\text { types of load } \\
\text { models } \\
\text { considered } \\
\text { in the } \\
\text { analysis. }\end{array}$ & $\begin{array}{l}\text { Narayan } \\
\text { S. Rau, } \\
\text { SM Yih- } \\
\text { heui Wan, } \\
\text { M [23] }\end{array}$ \\
\hline
\end{tabular}


Table 2. Different Methods Used in Siting and Sizing DG with Test System, Result and Observed Gaps

\begin{tabular}{|c|c|c|c|c|c|}
\hline $\begin{array}{l}\mathrm{S} / \\
\mathrm{N}\end{array}$ & Methodology & Test System & Result & Gaps & Reference \\
\hline $\begin{array}{l}\mathrm{B} \\
9\end{array}$ & $\begin{array}{l}\text { META-HEURISTIC } \\
\text { Differential Evolution }\end{array}$ & $\begin{array}{l}\text { IEEE 33-bus } \\
\text { radial } \\
\text { system } \\
\text { consisting of } \\
32 \text { sections. }\end{array}$ & $\begin{array}{l}\text { System losses reduced by } 47 \% \\
\text { for the installation of one DG. } \\
\text { The nodes violating the voltage } \\
\text { limits reduced to } 3 \text { from } 18 \text { and } \\
\text { the sum of squares of voltage } \\
\text { error dropped from } 0.1369 \text { p.u. } \\
\text { to } 0.02968 \text { p.u. }\end{array}$ & $\begin{array}{l}\text { It did not } \\
\text { consider } \\
\text { different } \\
\text { types of } \\
\text { loads in the } \\
\text { analysis. } \\
\text { Single DG } \\
\text { was } \\
\text { considered }\end{array}$ & $\begin{array}{l}\text { M. } \\
\text { Abbagana, } \\
\text { G. A. } \\
\text { Bakare, } \\
\text { and I. } \\
\text { Mustapha } \\
\text { [4] }\end{array}$ \\
\hline 10 & $\begin{array}{l}\text { Discrete particle } \\
\text { swarm optimization } \\
\text { (DPSO) technique }\end{array}$ & $\begin{array}{l}69 \text {-bus } \\
\text { radial } \\
\text { distribution } \\
\text { test network }\end{array}$ & $\begin{array}{l}\text { Proposed DPSO yields better } \\
\text { result compared to analycal } \\
\text { methods, GA and } A B C \text {. }\end{array}$ & $\begin{array}{l}\text { It did not } \\
\text { consider } \\
\text { different } \\
\text { types of } \\
\text { loads in the } \\
\text { analysis. }\end{array}$ & $\begin{array}{l}\text { Idris Musa } \\
\text { Shady } \\
\text { Gadoue, } \\
\text { and } \\
\text { Bashar } \\
\text { Zahawi } \\
\text { [24] }\end{array}$ \\
\hline 11 & $\begin{array}{l}\text { Improved Genetic } \\
\text { Algorithm (IGA), DG } \\
\text { integration }\end{array}$ & $\begin{array}{l}\text { Model } \\
\text { distribution } \\
\text { network }\end{array}$ & $\begin{array}{l}\text { IGA helps to improve the } \\
\text { network reconfiguration by } \\
\text { reducing total non-restored } \\
\text { loads from } 488 \mathrm{~A} \text { (with } 118.8 \mathrm{~kW} \\
\text { losses) to } 151 \mathrm{~A} \text { (with } 311.1 \mathrm{~kW} \\
\text { losses). Upon integration of DG, } \\
\text { the total non-restored loads } \\
\text { further reduced to } 68 \mathrm{~A} \text {. }\end{array}$ & $\begin{array}{l}\text { It did not use } \\
\text { standard } \\
\text { test system. } \\
\text { However, } \\
\text { the method } \\
\text { employed } \\
\text { did not } \\
\text { reduce } \\
\text { losses on } \\
\text { the line as } \\
\text { the lost } \\
\text { loads were } \\
\text { restored, but } \\
\text { rather } \\
\text { increased it. }\end{array}$ & $\begin{array}{l}\text { M. Shahrin } \\
\text { A. H. et al. } \\
\text { [26] }\end{array}$ \\
\hline 12 & $\begin{array}{l}\text { Ant colony } \\
\text { optimization (ACO) } \\
\text { algorithm } \\
\text { implemented in the } \\
\text { hyper cube (HC) } \\
\text { framework and } \\
\text { random search } \\
\text { musician-behavior- } \\
\text { inspired evolutionary } \\
\text { algorithm, harmony } \\
\text { search (HS) }\end{array}$ & $\begin{array}{l}\text { 32-bus and } \\
69 \text {-bus } \\
\text { distribution } \\
\text { systems }\end{array}$ & $\begin{array}{l}\text { Both methods are viable in the } \\
\text { sense that they give a } \\
\text { configuration with minimal } \\
\text { losses. }\end{array}$ & $\begin{array}{l}\text { The } \\
\text { simulation } \\
\text { did not } \\
\text { consider } \\
\text { optimal } \\
\text { siting or } \\
\text { sizing of DG }\end{array}$ & $\begin{array}{l}\text { ALMOATA } \\
\text { Z Y. } \\
\text { ABDELAZI } \\
\text { Z, et al. [6] }\end{array}$ \\
\hline 13 & $\begin{array}{l}\text { Particle swarm } \\
\text { algorithm based } \\
\text { on two-dimensional } \\
\text { depth-coded }\end{array}$ & IEEE69-bus & $\begin{array}{l}\text { Proposed method has fast } \\
\text { convergence with restoration of } \\
\text { all outages }\end{array}$ & $\begin{array}{l}\text { It did not } \\
\text { consider } \\
\text { optimal } \\
\text { location of } \\
\text { DGs for } \\
\text { minimal loss } \\
\text { and voltage } \\
\text { improve- } \\
\text { ment }\end{array}$ & $\begin{array}{l}\text { Chen Dan } \\
\text { et al. [27] }\end{array}$ \\
\hline 14 & $\begin{array}{l}\text { Teaching and } \\
\text { Learning-Based } \\
\text { Optimization (TLBO) }\end{array}$ & $\begin{array}{l}\text { IEEE 33-bus } \\
\text { and IEEE } \\
69 \text {-bus } \\
\text { radial } \\
\text { distribution } \\
\text { systems }\end{array}$ & $\begin{array}{l}\text { TLBO was compared with GA } \\
\text { and PSO. TLBO gave results } \\
\text { with minimal loss, higher voltage } \\
\text { profile and higher DG size. }\end{array}$ & $\begin{array}{l}\text { It did not } \\
\text { specify the } \\
\text { type of DG } \\
\text { technology } \\
\text { used and } \\
\text { types of load } \\
\text { models } \\
\text { considered } \\
\text { in the } \\
\text { analysis. }\end{array}$ & $\begin{array}{l}\text { Phanindra } \\
\text { k.G. and } \\
\text { Chintham } \\
\text { V. [28] }\end{array}$ \\
\hline
\end{tabular}


Table 2. Different Methods Used in Siting and Sizing DG with Test System, Result and Observed Gaps

\begin{tabular}{|c|c|c|c|c|c|}
\hline $\begin{array}{l}\mathrm{S} / \\
\mathrm{N}\end{array}$ & Methodology & Test System & Result & Gaps & Reference \\
\hline 15 & $\begin{array}{l}\text { Backtracking Search } \\
\text { Optimization } \\
\text { Algorithm (B.S.A) }\end{array}$ & $\begin{array}{l}\text { IEEE 69-bus } \\
\text { test system }\end{array}$ & $\begin{array}{l}\text { B.S.A was compared with } \\
\text { Harmony Search Algorithm } \\
\text { (H.S.A) and Artificial Bee Colony } \\
\text { Algorithm (A.B.C) and the } \\
\text { results showed that B.S.A had } \\
\text { the least loss and the most } \\
\text { improved voltage }\end{array}$ & $\begin{array}{l}\text { It did not } \\
\text { consider } \\
\text { network } \\
\text { restoration } \\
\text { and } \\
\text { reliability } \\
\text { indices of } \\
\text { the network }\end{array}$ & $\begin{array}{l}\text { Vivek } \\
\text { Gupta, } \\
\text { Sudha } \\
\text { Rani } \\
\text { Donepudi, } \\
\text { N. } \\
\text { Subrahma } \\
\text { nyam [29] }\end{array}$ \\
\hline 16 & $\begin{array}{l}\text { Goal attainment } \\
\text { method }\end{array}$ & $\begin{array}{l}\text { IEEE 34-bus } \\
\text { test system }\end{array}$ & $\begin{array}{l}\text { The proposed algorithm } \\
\text { calculates the reactive power } \\
\text { injections by the DG and the } \\
\text { reactive power compensation } \\
\text { devices, such that not only the } \\
\text { system bus voltages are } \\
\text { regulated, but also reduces the } \\
\text { total power loss. }\end{array}$ & $\begin{array}{l}\text { It did not } \\
\text { consider } \\
\text { optimal } \\
\text { location and } \\
\text { size of DGs. } \\
\text { It did also } \\
\text { consider } \\
\text { harmonic } \\
\text { effect of the } \\
\text { DGs }\end{array}$ & $\begin{array}{l}\text { Vahid } \\
\text { Asgharian, } \\
\text { V.M. } \\
\text { Istemihan } \\
\text { Genc [30] }\end{array}$ \\
\hline 17 & $\begin{array}{l}\text { Particle Swarm } \\
\text { Optimization (PSO) }\end{array}$ & $\begin{array}{l}\text { 38-bus } \\
\text { radial } \\
\text { system and } \\
\text { an IEEE 30- } \\
\text { bus meshed } \\
\text { system }\end{array}$ & $\begin{array}{l}\text { For } 38 \text {-bus system, the } \\
\text { reduction in the active power } \\
\text { loss was in the range of } 54- \\
67 \% \text {. The reduction in the } \\
\text { reactive power loss was in the } \\
\text { range of } 58-67 \% \text {. The reduction } \\
\text { in the total MVA intake was } \\
\text { about } 30 \% \text {. For the } 30 \text {-bus } \\
\text { system, the reduction in the } \\
\text { active power loss was in the } \\
\text { range of } 30-37 \% \text {. The reduction } \\
\text { in the reactive power loss was in } \\
\text { the range of } 26-31 \% \text {. The } \\
\text { reduction in the total MVA intake } \\
\text { was about } 62 \% \text {. }\end{array}$ & $\begin{array}{l}\text { The author } \\
\text { limits the } \\
\text { number of } \\
\text { DGs to three } \\
\text { before } \\
\text { simulation } \\
\text { was carried } \\
\text { out }\end{array}$ & $\begin{array}{l}\text { A.M. El- } \\
\text { Zonkoly } \\
{[31]}\end{array}$ \\
\hline 18 & $\begin{array}{l}\text { Particle Swarm } \\
\text { Optimization }\end{array}$ & $\begin{array}{l}\text { 12-bus, } 30- \\
\text { bus and } 69- \\
\text { bus test } \\
\text { systems }\end{array}$ & $\begin{array}{l}\text { The proposed method } \\
\text { converged for all the cases } \\
\text { observed in each test system. } \\
\text { The optimal number of DGs for } \\
\text { the test systems is two. }\end{array}$ & $\begin{array}{l}\text { When two } \\
\text { DGs were } \\
\text { considered, } \\
\text { the optimal } \\
\text { location } \\
\text { remained } \\
\text { the same as } \\
\text { the case of } \\
\text { single DG. It } \\
\text { did not } \\
\text { specify the } \\
\text { type of DG } \\
\text { technology } \\
\text { used. }\end{array}$ & $\begin{array}{l}\text { Naveen } \\
\text { Jain, S.N. } \\
\text { Singh, and } \\
\text { S.C. } \\
\text { Srivastava } \\
\text { [32] }\end{array}$ \\
\hline $\begin{array}{c}C \\
19\end{array}$ & $\begin{array}{l}\text { HYBRID } \\
\text { Voltage stability } \\
\text { index-based method } \\
\text { and Particle Swarm } \\
\text { Optimization }\end{array}$ & $\begin{array}{l}\text { A } 30 \text {-bus } \\
\text { test system } \\
\text { and a } 41- \\
\text { bus Indian } \\
\text { distribution } \\
\text { system }\end{array}$ & $\begin{array}{l}\text { It found optimal point between } \\
\text { benefit from DG placement and } \\
\text { DG sizing for minimal loss and } \\
\text { improved voltage profile. }\end{array}$ & $\begin{array}{l}\text { It did not } \\
\text { provide } \\
\text { justification } \\
\text { for the factor } \\
\text { used. }\end{array}$ & $\begin{array}{l}\text { Naveen } \\
\text { Jain [33] }\end{array}$ \\
\hline 20 & $\begin{array}{l}\text { Fuzzy adaptive } \\
\text { hybrid particle } \\
\text { swarm optimization } \\
\text { (FAHPSO) method }\end{array}$ & $\begin{array}{l}\text { Modified } \\
\text { version of } \\
\text { the IEEE 33- } \\
\text { node } \\
\text { distribution } \\
\text { system. }\end{array}$ & $\begin{array}{l}\text { FAHPSO searched better } \\
\text { schedule for the studied } \\
\text { distribution network using fewer } \\
\text { evolution cycles, compared with } \\
\text { HPSO method. }\end{array}$ & $\begin{array}{l}\text { Thermal } \\
\text { effect was } \\
\text { ignored }\end{array}$ & $\begin{array}{l}\text { Shuheng } \\
\text { Chen et al. } \\
\text { [34] }\end{array}$ \\
\hline
\end{tabular}


Table 2. Different Methods Used in Siting and Sizing DG with Test System, Result and Observed Gaps

\begin{tabular}{|c|c|c|c|c|c|}
\hline $\begin{array}{l}\mathrm{S} / \\
\mathrm{N}\end{array}$ & Methodology & Test System & Result & Gaps & Reference \\
\hline 21 & $\begin{array}{l}\text { GA, Power flow and } \\
\text { Analytical methods }\end{array}$ & $\begin{array}{l}\text { Brazilian } \\
\text { actual } \\
\text { distribution } \\
\text { system }\end{array}$ & $\begin{array}{l}\text { In terms of power flow, the } \\
\text { maximum voltage drop was } \\
\text { reduced to } 0.022404 \mathrm{pu}(3 \%) \\
\text { and the losses became } 85.4 \mathrm{~kW} \\
(83.74 \%) \text { after DG allocation. }\end{array}$ & $\begin{array}{l}\text { It did not } \\
\text { consider } \\
\text { optimal } \\
\text { location and } \\
\text { sizing of DG. } \\
\text { It is only } \\
\text { limited to a } \\
\text { location and } \\
\text { some } \\
\text { specified } \\
\text { values of } \\
\text { DG capacity. }\end{array}$ & $\begin{array}{l}\text { Carmen } \\
\text { L.T. } \\
\text { Borges, } \\
\text { Djalma M. } \\
\text { Falcao } \\
\text { [35] }\end{array}$ \\
\hline 22 & $\begin{array}{l}\text { Sensitivity-based } \\
\text { approach and } \\
\text { Modified Primal-Dual } \\
\text { Interior Point } \\
\text { Algorithm (MPDIPA) }\end{array}$ & $\begin{array}{l}\text { IEEE 123- } \\
\text { node test } \\
\text { feeder }\end{array}$ & $\begin{array}{l}\text { The proposed approach i.e. } \\
\text { MPDIPA searches for the } \\
\text { optimal solutions quickly with } \\
\text { improvement in the voltage } \\
\text { profile and obvious reduction in } \\
\text { network loss. }\end{array}$ & $\begin{array}{l}\text { It did not } \\
\text { specify the } \\
\text { type of DG } \\
\text { technology } \\
\text { likewise, it } \\
\text { did not } \\
\text { consider } \\
\text { different } \\
\text { types of } \\
\text { loads model } \\
\text { in the } \\
\text { analysis. }\end{array}$ & $\begin{array}{l}\text { Zhipeng } \\
\text { Liu, } \\
\text { Fushuan } \\
\text { Wen, } \\
\text { Gerard } \\
\text { Ledwich } \\
\text { and } \\
\text { Xingquan } \\
\text { Ji [36] }\end{array}$ \\
\hline 23 & $\begin{array}{l}\text { Rank Evolutionary } \\
\text { Particle Swarm } \\
\text { Optimization } \\
\text { (REPSO), } \\
\text { Evolutionary Particle } \\
\text { Swarm Optimization } \\
\text { (EPSO), and } \\
\text { Traditional Particle } \\
\text { Swarm Optimization } \\
\text { (PSO) method }\end{array}$ & $\begin{array}{l}69-\text {-bus } \\
\text { radial } \\
\text { distribution } \\
\text { system }\end{array}$ & $\begin{array}{l}\text { REPSO converges faster than } \\
\text { EPSO and PSO and gives a } \\
\text { better standard deviation. There } \\
\text { is } 47 \% \text { loss reduction }\end{array}$ & $\begin{array}{l}\text { The method } \\
\text { is limited to } \\
\text { optimasation } \\
\text { of already } \\
\text { placed or } \\
\text { installed DG. }\end{array}$ & $\begin{array}{l}\text { J.J. } \\
\text { Jamian et } \\
\text { al. [25] }\end{array}$ \\
\hline 24 & $\begin{array}{l}\text { Mixed integer } \\
\text { quadratic constraint } \\
\text { programming } \\
\text { (MIQCP) model and } \\
\text { information gap } \\
\text { decision theory } \\
\text { (IGDT) using Robust } \\
\text { Restoration } \\
\text { Optimisation(RRO) } \\
\text { and Determined } \\
\text { Restoration } \\
\text { Optimisation(DRO) }\end{array}$ & $\begin{array}{l}\text { Modified } \\
\text { Pacific Gas } \\
\text { and Electric } \\
\text { Company } \\
\text { (PG\&E) 69- } \\
\text { node } \\
\text { distribution } \\
\text { network }\end{array}$ & $\begin{array}{l}\text { RRO offers stable automatic } \\
\text { strategies which meet the } \\
\text { essential of self-healing that is } \\
\text { absent in DRO }\end{array}$ & $\begin{array}{l}\text { The method } \\
\text { is limited to } \\
\text { optimasation } \\
\text { of already } \\
\text { sized and } \\
\text { placed or } \\
\text { installed DG. } \\
\text { This means } \\
\text { that if the } \\
\text { DG(s) were } \\
\text { wrongly } \\
\text { placed, this } \\
\text { method } \\
\text { cannot } \\
\text { identify or } \\
\text { correct the } \\
\text { error. }\end{array}$ & $\begin{array}{l}\text { Kening } \\
\text { Chen et al. } \\
{[27]}\end{array}$ \\
\hline 25 & $\begin{array}{l}\text { Cat-Swarm- } \\
\text { Optimization (CSO) } \\
\text { and composite } \\
\text { reliability index, } \\
\text { AWPSO, PSO-CF }\end{array}$ & $\begin{array}{l}\text { 34-bus } \\
\text { radial test } \\
\text { distribution } \\
\text { system and } \\
\text { IEEE } 69 \text { bus } \\
\text { radial test } \\
\text { distribution } \\
\text { system }\end{array}$ & $\begin{array}{l}\text { CSO yields better performance } \\
\text { as compared to AWPSO and } \\
\text { PSO-CF in terms of active } \\
\text { power loss reduction, power } \\
\text { transfer capacity and } \\
\text { computational time }\end{array}$ & $\begin{array}{l}\text { It did not } \\
\text { consider } \\
\text { optimal } \\
\text { sizing of } \\
\text { DGs and } \\
\text { bus voltage } \\
\text { limit }\end{array}$ & $\begin{array}{l}\text { Deepak } \\
\text { Kumar } \\
\text { and S. R. } \\
\text { Samantar } \\
\text { ay [37] }\end{array}$ \\
\hline
\end{tabular}


Table 2. Different Methods Used in Siting and Sizing DG with Test System, Result and Observed Gaps

\begin{tabular}{|c|c|c|c|c|c|}
\hline $\begin{array}{l}\mathrm{S} / \\
\mathrm{N}\end{array}$ & Methodology & Test System & Result & Gaps & Reference \\
\hline 26 & $\begin{array}{l}\text { Non-dominated } \\
\text { sorting genetic } \\
\text { algorithm (NSGA-II) } \\
\text { and fuzzy decision- } \\
\text { making analysis }\end{array}$ & $\begin{array}{l}\text { IEEE 69-bus } \\
\text { test system }\end{array}$ & $\begin{array}{l}\text { The application of network } \\
\text { reconfiguration, shunt capacitors } \\
\text { and distributed generators } \\
\text { altogether on distribution system } \\
\text { enhancement yields better } \\
\text { system performance when } \\
\text { compared to the application of } \\
\text { only one or two options. }\end{array}$ & $\begin{array}{l}\text { The number, } \\
\text { size, and set } \\
\text { of locations } \\
\text { of capacitors } \\
\text { and DGs are } \\
\text { limited to } \\
\text { pre-defined } \\
\text { value }\end{array}$ & $\begin{array}{l}\text { Russel } \\
\text { John C. } \\
\text { Gallano } \\
\text { and Allan } \\
\text { C. Nerves } \\
\text { [8] }\end{array}$ \\
\hline 27 & $\begin{array}{l}\text { Ranked Evolutionary } \\
\text { particle swarm } \\
\text { optimization } \\
\text { (REPSO) }\end{array}$ & $\begin{array}{l}\text { IEEE 69-bus } \\
\text { test system }\end{array}$ & $\begin{array}{l}\text { The result indicates that as the } \\
\text { number of DG units installed } \\
\text { increases, the power loss } \\
\text { reduction also increases and } \\
\text { voltage profile increases. }\end{array}$ & $\begin{array}{l}\text { The method } \\
\text { used to } \\
\text { locate DG } \\
\text { placement } \\
\text { can be } \\
\text { localised. } \\
\text { The analysis } \\
\text { did not } \\
\text { consider } \\
\text { load } \\
\text { variation }\end{array}$ & $\begin{array}{l}\text { Haruna } \\
\text { Musa, } \\
\text { Sanusi } \\
\text { Sani } \\
\text { Adamu } \\
\text { [38] }\end{array}$ \\
\hline 28 & $\begin{array}{l}\text { Fuzzy adaptive } \\
\text { hybrid particle } \\
\text { swarm optimization } \\
\text { (FAHPSO) method }\end{array}$ & $\begin{array}{l}\text { EEE 33- } \\
\text { node } \\
\text { distribution } \\
\text { system with } \\
\text { two newly } \\
\text { installed } \\
\text { distributed } \\
\text { generators } \\
\text { and eight } \\
\text { newly } \\
\text { installed } \\
\text { capacitors } \\
\text { banks. }\end{array}$ & $\begin{array}{l}\text { FAHPSO gives better } \\
\text { convergence and search } \\
\text { schedule for the studied } \\
\text { distribution network using fewer } \\
\text { evolution cycles, compared with } \\
\text { HPSO method. }\end{array}$ & $\begin{array}{l}\text { It did not } \\
\text { consider } \\
\text { optimal } \\
\text { location of } \\
\text { DGs for } \\
\text { minimal loss }\end{array}$ & $\begin{array}{l}\text { Shuheng } \\
\text { Chen et al. } \\
{[34]}\end{array}$ \\
\hline 29 & Fuzzy-GA method & $\begin{array}{l}=12 \text {-bus } \\
\text { sample } \\
\text { systems }\end{array}$ & $\begin{array}{l}\text { Aside improvement in voltage } \\
\text { profile, the result also shows that } \\
\text { there will be } \$ 7,554.5 \text { saving } \\
\text { costs in } 10 \text { years }\end{array}$ & $\begin{array}{l}\text { It did not } \\
\text { specify the } \\
\text { type of DG } \\
\text { technology } \\
\text { used and } \\
\text { types of } \\
\text { loads model } \\
\text { considered } \\
\text { in the } \\
\text { analysis. }\end{array}$ & $\begin{array}{l}\text { Kyu-Ho } \\
\text { Kim, Yu- } \\
\text { Jeong Lee } \\
\text { and Sang- } \\
\text { Bong } \\
\text { Rhee, } \\
\text { Sang- } \\
\text { Kuen Lee } \\
\text { and Seok- } \\
\text { Ku You } \\
\text { [39] }\end{array}$ \\
\hline
\end{tabular}

Table 3. Comparison of Different Methods Used

\begin{tabular}{|c|c|c|c|}
\hline $\mathrm{S} / \mathrm{N}$ & $\begin{array}{c}\text { Optimization } \\
\text { method }\end{array}$ & Benefits & Drawback \\
\hline 1 & Analytical & $\begin{array}{l}\text { - Computing time is short } \\
\text { - Easy to implement } \\
\text { - Non-iterative in nature } \\
\text { - Unlike other techniques, does not pose } \\
\text { convergence problems }\end{array}$ & $\begin{array}{l}\text { When problem becomes complex, } \\
\text { assumptions used in order to simplify } \\
\text { problem may override accuracy of } \\
\text { solution } \\
\text { - Lacks robustness }\end{array}$ \\
\hline 2 & $\begin{array}{c}\text { Meta- } \\
\text { Heuristic }\end{array}$ & $\begin{array}{l}\text { - Can rapidly locate solutions, even for } \\
\text { large search space } \\
\text { - Works with discrete and continuous } \\
\text { parameters } \\
\text { - Bad proposals do not affect end solution } \\
\text { negatively } \\
\text { - Very useful for complex problems }\end{array}$ & $\begin{array}{l}\text { - Repeated fitness function evaluation } \\
\text { for large and complex problems may } \\
\text { be time consuming } \\
\text { - May not suggest best solution always, } \\
\text { possibility of trapping into local optima } \\
\text { - Lack of accuracy, not suitable when a } \\
\text { high-quality solution is required }\end{array}$ \\
\hline 3 & Hybrid & $\begin{array}{l}\text { - Higher efficiency } \\
\text { - Higher possibility of global optima } \\
\text { - Less computational time }\end{array}$ & - Increased complexity \\
\hline
\end{tabular}




\section{Discussion}

Although several researchers have considered integration of distributed generation into EPS as an alternative to construction of centralised generation station, some prevailing research problems, which require more investigations, are still open and they are listed as follows:

a. One major prevailing problem in the planning of power system to incorporate DGs is to take into account various factors such as nature of DG technology, impact of DG on operating characteristics of power system and economic considerations [40].

b. Another problem of integrating DG into the grid is islanding issue for which IEEE 1547 standard [41] was established: a criterion for interconnection of DG sources. The present standards do not allow islanded operation of DG [42]

c. The possibility of reliability enhancement with increased penetration of RES-based DGs is another prevailing problem and it has also not been investigated. Likewise, the reliability assessment studies during islanded mode, incorporating RES-based DGs and storage has not been reported in literature. [40]

d. DGs integration impact on system reliability, line losses, emissions, voltage profile and cost for an optimum system planning [40].

\section{Conclusion}

This study gave a critical, comprehensive and systematic survey of the existing methods for integrating DG(s) into EPS in order to mitigate continuous increase in load demand.Three categories of optimasation techniques i.e. analytical, meta-heuristic and hybrid optimisation methods were considered. This categorization, as well asthe representative techniques described under each category, will benefit optimisation techniques'researchers for choosing from proper state-of-the-art population-initializationbased techniques for their research. The volume of the surveyed techniques revealed that optimisation techniques havebecome an active research topic in electrical power system domain. However, some questions are yet to beresolved. Some of these questions were highlighted for future investigation.

Based on the reviewed literature, this study also gave a review of different optimisation methodologies for siting and sizing distributed generators in a distribution network. The test systems/networks as well as results obtained from these methods were also recorded. The observed gaps in the reviewed literature were also provided and finally, the strengths and weaknesses of the available methods were also included. However, most of the previous works were carried out on conventional DGs. Though many researchers did not specify the DG technology employed, their analyses prove that RES were not considered. Therefore, recommendations for further studies in this area of research will include integration of RES into the grid, consideration for islanding in integrating DG into the grid and protection coordination of a network with $D G(s)$.

\section{Acknowledgements}

The authors would like to express special thanks and gratitude to Covenant University for their support.

\section{References}

[1] J Nweke, A Ekwue, E Ejiogu. Optimal Location of Distributed Generation on the Nigerian Power System. Nigerian Journal of Technology. 2016; 35: 398-403.

[2] S Chanda, ADA De. Congestion Relief of Contingent Power Network with Evolutionary Optimization Algorithm. TELKOMNIKA (Telecommunication Computing Electronics and Control). 2011; 10: 1-8.

[3] F Laouafi, A Boukadoum, S Leulmi. A Hybrid Formulation between Differential Evolution and Simulated Annealing Algorithms for Optimal Reactive Power Dispatch. TELKOMNIKA(Telecommunication Computing Electronics and Control). 2018; 16: 513-524.

[4] M Abbagana, G Bakare, I Mustapha. Optimal placement and sizing of a distributed generator in a power distribution system using differential evolution. in Proceedings of the 1 st International Technology, Education and Environment Conference. 2011: 536-549. 
[5] HI Hussein, GA Salman, MS Hasan. Phase Measurement Units based FACT's Devices for the Improvement of Power Systems Networks Controllability. International Journal of Electrical and Computer Engineering (IJECE). 2018; 8: 888-899.

[6] AY Abdelaziz, RA Osama, SM Elkhodary, EF El-Saadany. Reconfiguration of distribution systems with distributed generators using Ant Colony Optimization and Harmony Search algorithms. in 2012 IEEE Power and Energy Society General Meeting. 2012: 1-8.

[7] ME Baran, FF Wu. Network reconfiguration in distribution systems for loss reduction and load balancing. IEEE Transactions on Power delivery. 1989; 4: 1401-1407.

[8] RJC Gallano, AC Nerves. Multi-objective optimization of distribution network reconfiguration with capacitor and distributed generator placement. in TENCON 2014 - 2014 IEEE Region 10 Conference. 2014: 1-6.

[9] Zk LI, Xy CHEN, K Yu, Hm LIU, B Zhao. Hybrid particle swarm optimization for distribution network reconfiguration. Proceedings of the CSEE. 2008; 31: 35-41.

[10] J Olamaei, G Gharehpetian, T Niknam. An approach based on Particle Swarm Optimization for distribution feeder reconfiguration considering Distributed Generators. in 2007 Power Systems Conference: Advanced Metering, Protection, Control, Communication, and Distributed Resources. 2007: 326-330.

[11] J Savier, D Das. Impact of network reconfiguration on loss allocation of radial distribution systems. IEEE Transactions on Power Delivery. 2007; 22: 2473-2480.

[12] TM Masaud, G Nannapaneni, R Challoo. Optimal placement and sizing of distributed generation-based wind energy considering optimal self VAR control. IET Renewable Power Generation. 2017; 11: 281-288.

[13] AA Eajal, M El-Hawary. Optimal capacitor placement and sizing in unbalanced distribution systems with harmonics consideration using particle swarm optimization. IEEE Transactions on Power Delivery. 2010; 25: 1734-1741.

[14] SJ Huang. An immune-based optimization method to capacitor placement in a radial distribution system. IEEE Transactions on Power Delivery. 2000; 15: 744-749.

[15] YJ Kim, JL Kirtley, LK Norford. Reactive Power Ancillary Service of Synchronous DGs in Coordination With Voltage Control Devices. IEEE Transactions on Smart Grid. 2017; 8: 515527.

[16] S Sultana, PK Roy. Optimal capacitor placement in radial distribution systems using teaching learning based optimization. International Journal of Electrical Power \& Energy Systems. 2014; 54: 387-398.

[17] T Gözel, MH Hocaoglu. An analytical method for the sizing and siting of distributed generators in radial systems. Electric Power Systems Research. 2009; 79: 912-918.

[18] S Ghosh, SP Ghoshal, S Ghosh. Optimal sizing and placement of distributed generation in a network system. International Journal of Electrical Power \& Energy Systems. 2010; 32: 849856.

[19] T Gozel, MH Hocaoglu, U Eminoglu, A Balikci. Optimal placement and sizing of distributed generation on radial feeder with different static load models. in 2005 International Conference on Future Power Systems. 2005: 2-6.

[20] HM Ayres, D Salles, W Freitas. A Practical Second-Order Based Method for Power Losses Estimation in Distribution Systems With Distributed Generation. IEEE Transactions on Power Systems. 2014; 29: 666-674.

[21] N Acharya, P Mahat, N Mithulananthan. An analytical approach for DG allocation in primary distribution network. International Journal of Electrical Power \& Energy Systems. 2006; 28: 669-678.

[22] P Alemi, G Gharehpetian. DG allocation using an analytical method to minimize losses and to improve voltage security. in Power and Energy Conference, 2008. PECon 2008. IEEE 2nd International. 2008: 1575-1580.

[23] NS Rau, Yh Wan. Optimum location of resources in distributed planning. IEEE Transactions on Power systems. 1994; 9: 2014-2020.

[24] I Musa, S Gadoue, B Zahawi. Integration of distributed generation in power networks considering constraints on discrete size of distributed generation units. Electric Power Components and Systems. 2014; 42: 984-994

[25] JJ Jamian, MW Mustafa, H Mokhlis, MN Abdullah. Comparative Study on Distributed Generator Sizing Using Three Types of Particle Swarm Optimization. in 2012 Third International Conference on Intelligent Systems Modelling and Simulation. 2012: 131-136.

[26] MSAH, K Nosu, H Aoki. Integrating Distributed Generator for restoration optimization. in 2012 IEEE International Conference on Power and Energy (PECon). 2012: 773-777.

[27] K Chen, W Wu, B Zhang, H Sun. Robust Restoration Decision-Making Model for Distribution Networks Based on Information Gap Decision Theory. IEEE Transactions on Smart Grid. 2015; 6: 587-597. 
[28] PK Ganivada, C Venkaiah. Optimal placement and sizing of multi distributed generators using teaching and learning based optimization. in 2014 International Conference on Smart Electric Grid (ISEG). 2014: 1-6.

[29] V Gupta, SR Donepudi, N Subrahmanyam. Optimal placement of distributed generators in distribution system using backtracking search optimization for various load models. in 2015 International Conference on Recent Developments in Control, Automation and Power Engineering (RDCAPE). 2015: 350-354.

[30] V Asgharian, VMI Genc. Multi-objective optimization for voltage regulation in distribution systems with distributed generators. in 2016 IEEE Electrical Power and Energy Conference (EPEC). 2016: 1-6.

[31] A El-Zonkoly. Optimal placement of multi-distributed generation units including different load models using particle swarm optimization. Swarm and Evolutionary Computation. 2011; 1: 5059.

[32] N Jain, S Singh, S Srivastava. Particle swarm optimization based method for optimal siting and sizing of multiple distributed generators. in Proceedings of 16th National Power Systems Conference. 2010: 669-674.

[33] N Jain, SN Singh, SC Srivastava. Planning and impact evaluation of distributed generators in Indian context using Multi-Objective Particle Swarm Optimization. in 2011 IEEE Power and Energy Society General Meeting. 2011: 1-8.

[34] S Chen, W Hu, C Su, X Zhang, Z Chen. Optimal reactive power and voltage control in distribution networks with distributed generators by fuzzy adaptive hybrid particle swarm optimisation method. IET Generation, Transmission \& Distribution. 2015; 9: 1096-1103.

[35] CL Borges, DM Falcao. Optimal distributed generation allocation for reliability, losses, and voltage improvement. International Journal of Electrical Power \& Energy Systems. 2006; 28: 413-420.

[36] Z Liu, F Wen, G Ledwich, X Ji. Optimal sitting and sizing of distributed generators based on a modified primal-dual interior point algorithm. in 2011 4th International Conference on Electric Utility Deregulation and Restructuring and Power Technologies (DRPT). 2011: 1360-1365.

[37] D Kumar, SR Samantaray. Reliability optimization for optimal placement of multiple distributed generators in primary distribution network using an evolutionary approach. in 2014 Students Conference on Engineering and Systems. 2014: 1-6.

[38] H Musa, SS Adamu. Optimal allocation and sizing of distributed generation for power loss reduction using modified PSO for radial distribution systems. Journal of Energy Technologies and Policy. 2013; 3: 1-9.

[39] KH Kim, YJ Lee, SB Rhee, SK Lee, SK You. Dispersed generator placement using fuzzy-GA in distribution systems. in 2002 IEEE Power Engineering Society Summer Meeting. 2002: 11481153.

[40] P Paliwal, N Patidar, R Nema. Planning of grid integrated distributed generators: a review of technology, objectives and techniques. Renewable and sustainable energy reviews. 2014; 40: 557-570.

[41] DG Photovoltaics, E Storage. IEEE Application Guide for IEEE Std $1547^{\mathrm{TM}}$, IEEE Standard for Interconnecting Distributed Resources with Electric Power Systems. 2009.

[42] PP Barker, RW De Mello. Determining the impact of distributed generation on power systems. I. Radial distribution systems. in 2000. IEEE Power Engineering Society Summer Meeting. 2000: 1645-1656. 